\title{
Correction to: Risk management methodology in the supply chain: a case study applied
}

\author{
M. J. Hermoso-Orzáez ${ }^{1}$ (D) · J. Garzón-Moreno ${ }^{1}$
}

(c) The Author(s) 2022

\section{Correction to: Annals of Operations Research https://doi.org/10.1007/s10479-021-04220-y}

This erratum is published as the article mistakenly contained Spanish language text in Sect. 2, Table 3, and Table 4.

The second sentence of Sect. 2 should read "This document aims to identify, classify and prioritize the risks of the supply chain faced by small and medium-sized companies manufacturing bread and derivatives to develop a methodology for managing risks of the supply chain" or it can be eliminated."

In Tables 3 and 4 "Catastrofic" and "Catastrofico" should read as "Catastrophic" and "Critico" should read as "Critical."

Thus, this erratum is presented to correct the errors.

Open Access This article is licensed under a Creative Commons Attribution 4.0 International License, which permits use, sharing, adaptation, distribution and reproduction in any medium or format, as long as you give appropriate credit to the original author(s) and the source, provide a link to the Creative Commons licence, and indicate if changes were made. The images or other third party material in this article are included in the article's Creative Commons licence, unless indicated otherwise in a credit line to the material. If material is not included in the article's Creative Commons licence and your intended use is not permitted by statutory regulation or exceeds the permitted use, you will need to obtain permission directly from the copyright holder. To view a copy of this licence, visit http://creativecommons.org/licenses/by/4.0/.

Publisher's Note Springer Nature remains neutral with regard to jurisdictional claims in published maps and institutional affiliations.

The original article can be found online at https://doi.org/10.1007/s10479-021-04220-y.

$凶$ M. J. Hermoso-Orzáez

mhorzaez@ujaen.es

J. Garzón-Moreno

joaquingarzon.jg@gmail.com

1 Department of Graphic Engineering Design and Projects, University of Jaén, Jaén, Spain 